\title{
Intestinal cellular proliferation and protein synthesis in zinc-deficient rats
}

\author{
By SUSAN SOUTHON, G. LIVESEY, JENNIFER M. GEE AND \\ I. T. JOHNSON \\ AFRC Food Research Institute, Colney Lane, Norwich NR4 7UA
}

\author{
(Received 30 August 1984 - Accepted 3 December 1984)
}

\begin{abstract}
1. Immature male Wistar rats were given a low-zinc semi-synthetic diet ( $2 \mathrm{mg} \mathrm{Zn} / \mathrm{kg}$ ) for $28 \mathrm{~d}$. Control groups received a similar diet supplemented with $58 \mathrm{mg} \mathrm{Zn} / \mathrm{kg}$ either $a d$ lib. or in amounts matched to the consumption of the $\mathrm{Zn}$-deficient group. Rates of growth, food consumption and small intestinal length were significantly reduced in the $\mathrm{Zn}$-depleted rats.

2. $\mathrm{Zn}$ deficiency in the rat was associated with a reduction in the ratio, crypt: villus and a lower rate of crypt cell division in the jejunum. This resulted in a substantial decrease in the net influx of new cells into the villi of the $\mathrm{Zn}$-deficient animals compared with controls.

3. The fractional rates of protein synthesis in jejunal mucosa were measured by a technique based on the determination of $\mathrm{L}-\left[4-{ }^{3} \mathrm{H}\right]$ phenylalanine incorporation. There was no evidence of a decline in the protein synthetic rate in total mucosa from $\mathrm{Zn}$-deficient rats.

4. It is suggested that a reduction in cell influx into the villi may be responsible for the morphological and functional changes observed in the small intestine of rats fed on a low- $\mathrm{Zn}$ diet.
\end{abstract}

One of the first observable signs of zinc deficiency is a severe retardation of growth and development which has been associated with the requirement for $\mathrm{Zn}$ metalloenzymes in the synthesis of nucleic acids and protein (Prasad \& Oberleas, 1973; Duncan \& Dreosti, 1976). The mucosa of the small intestine has one of the most rapid turnover rates of any tissue in the body (Messier \& Leblond, 1960; Lipkin et al. 1963) together with a very high rate of protein synthesis (McNurlan et al. 1979). It seems probable, therefore, that the rapidly proliferating cells of the intestinal mucosa would be particularly sensitive to $\mathrm{Zn}$ deficiency with consequent changes in gastrointestinal structure and function.

A previous study (Southon et al. 1984) revealed that dietary $\mathrm{Zn}$ depletion is associated with distinct morphological changes in the jejunum. These changes include a shortening and narrowing of jejunal villi and an increased number of villi per unit area of jejunum. Furthermore, this was accompanied by a marked enhancement of carrier-mediated hexose uptake. It was postulated that a reduction in mucosal cell proliferation and a slowing of cell migration along the villus might allow more time for the development of carrier capacity, which in turn might account for the increased rates of hexose uptake observed in $\mathrm{Zn}$-depleted animals. A decrease in the rate of supply of cells to the villi may also be responsible for the morphological changes in mucosa of $\mathrm{Zn}$-deficient rats.

The present study was undertaken to investigate the effect of dietary $\mathrm{Zn}$ depletion on the rate of mucosal cell production in the rat and to determine whether any changes are associated with an alteration in the rate of protein synthesis.

\section{MATERIALS AND METHODS \\ Animals and diets}

Male Wistar rats (approximately $110 \mathrm{~g}$ ) were randomly divided into three groups of ten. The rats were caged in pairs in polypropylene cages with stainless-steel lids and gridded bottoms, in a room at $21^{\circ}$ having a $12 \mathrm{~h}-12 \mathrm{~h}$ light-dark cycle. The first group received a 
Table 1. Composition of semi-synthetic diet $(\mathrm{g} / \mathrm{kg}$ diet $)$

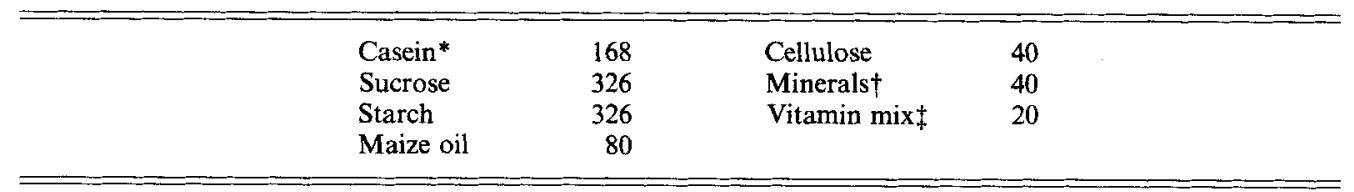

* EDTA washed.

$\dagger$ Minerals (g/kg diet): $\mathrm{CaHPO}_{4} 13 \cdot 00, \mathrm{CaCO}_{3} 8 \cdot 20, \mathrm{KCl} 7 \cdot 03, \mathrm{Na} 2 \mathrm{HPO}_{4} 7 \cdot 40, \mathrm{MgSO}_{4} \cdot \mathrm{H}_{2} \mathrm{O} 4 \cdot 00, \mathrm{MnSO}_{4} \cdot \mathrm{H}_{2} \mathrm{O}$ $0 \cdot 18, \mathrm{ZnCO}_{3} 0 \cdot 10$ (excluded from low-zinc diet), $\mathrm{FeSO}_{4} .7 \mathrm{H}_{2} \mathrm{O} 0 \cdot 144, \mathrm{CuSO}_{4} 0 \cdot 015, \mathrm{KIO}_{3} 0 \cdot 001$.

‡ Vitamin mix (mg/kg diet): nicotinic acid 60, cyanocobalamin in mannitol 50, calcium-D-pantothenate 40 , thiamin hydrochloride 10 , riboflavin 10 , pteroylmonoglutamic acid 5, D-biotin 1 , menadione 1 , Rovimix E-25 (Roche) 300, Rovimix A-500 (Roche) 25, Rovimix A-500/D3 (Roche) 15, choline bitartrate 1800.

powdered semi-synthetic diet containing $2 \mathrm{mg} \mathrm{Zn} / \mathrm{kg}$ diet. The two control groups of rats were given a similar diet supplemented with $58 \mathrm{mg} \mathrm{Zn} / \mathrm{kg}$ diet. One control group was feed restricted, that is, each cage of rats was given daily an amount of food equal to that consumed on the previous day by a paired cage of $\mathrm{Zn}$-deficient rats. The other control group was allowed to feed ad lib. The composition of the diet is shown in Table 1. Distilled water was provided ad lib. Food intakes were measured daily and body weights recorded twice weekly. The rats were maintained on the experimental diets for at least $28 \mathrm{~d}$.

\section{Mucosal cell production rate}

The rate of production of mucosal epithelial cells was estimated by a modification of the metaphase arrest technique (Wimber \& Lamberton, 1963). Estimates of the ratio, crypt: villus were obtained from the same tissue samples (Clarke, 1970). Three groups of ten animals were maintained on the experimental diets as described previously. On successive mornings (days 28, 29 and 30) animals in each group were given an intraperitoneal injection of vincristine sulphate (Sigma, Poole, Dorset) in distilled water $(1 \mathrm{mg} / \mathrm{kg}$ body-weight) and were killed at successive 12-min intervals. $\mathrm{Zn}$-deficient and ad lib.-fed control rats were allowed access to food until approximately $1 \mathrm{~h}$ before the vincristine injection. Pair-fed controls consumed their daily ration of food between 9.00 and 10.00 hours on the morning of killing and were injected $1 \mathrm{~h}$ later.

After death the entire small intestine was removed, flushed with saline $(9 \mathrm{~g}$ sodium chloride/l) and everted on the bench with minimal stretching. The proximal twelfth (duodenum) of the total length was discarded and the next $100 \mathrm{~mm}$ of jejunum removed to fixative (ethanol-acetic acid; 75:25, v/v). Sub-samples of the fixed intestine $(5-10 \mathrm{~mm})$ were passed through ethanol-water $(50: 50, \mathrm{v} / \mathrm{v} ; 10 \mathrm{~min})$ and distilled water $(10 \mathrm{~min})$ and stained in bulk by the Feulgen reaction. Subsequent manipulations were carried out in glacial acetic acid-water $(45: 55, \mathrm{v} / \mathrm{v})$. The total number of blocked metaphases was counted in microdissected crypts (ten per site) which were gently squashed beneath a coverslip and examined under the compound microscope. The cell division rate per crypt was determined by plotting the mean number of blocked metaphases $v$. time interval after injection and estimating the slope by linear regression. One animal in each group was excluded from the analysis because of the presence of anaphase nuclei in the crypts, indicating incomplete metaphase arrest.

Estimates of the number of crypts and villi per $\mathrm{mm}^{2}$ serosal surface were obtained by means of a dissecting microscope fitted with a calibrated eyepiece. 


\section{Fractional rates of protein synthesis}

The fractional rates of protein synthesis in small intestinal mucosa were determined by the technique of Reeds et al. (1982) with minor modifications. On the day of killing, $\mathrm{Zn}$-deficient and $a d$ lib.-fed control rats were allowed access to food until 10.00 hours and pair-fed controls consumed all their daily allowance of food between 9.00 and 10.00 hours. The experiments were conducted between 14.00 and 16.30 hours. Rats received an intraperitoneal injection of $\mathrm{L}-\left[4-{ }^{3} \mathrm{H}\right]$ phenylalanine solution in water $(50 \mu \mathrm{Ci} / \mathrm{ml} ; 150 \mu \mathrm{mol} / \mathrm{ml} ; 10 \mathrm{ml} / \mathrm{kg}$ body-weight) and were killed by cervical dislocation at 5 or $15 \mathrm{~min}$ after injection. The abdominal cavity was flushed with $75 \mathrm{ml}$ ice-cold saline solution $(9 \mathrm{~g}$ sodium chloride/l) to remove unabsorbed radioisotope. The entire small intestine was removed and flushed with ice-cold saline to remove food debris and extended on the bench with minimal stretching. The proximal twelfth (duodenum) of the total length was discarded and the next four twelfths (jejunum) were laid on a cooled glass plate, slit open and the mucosa scraped from the underlying muscle layer with a microscope slide.

Tissue samples were placed in pre-cooled homogenizing tubes, weighed, acidified with cold perchloric acid $(40 \mathrm{~g} / 1,6 \cdot 0 \mathrm{ml} / 0.5 \mathrm{~g}$ tissue $)$ and centrifuged. The supernatant fraction was neutralized with potassium hydroxide $(200 \mathrm{~g} / \mathrm{l})$. The protein pellets were washed three times with perchloric acid $(40 \mathrm{~g} / \mathrm{l}, 10 \mathrm{ml})$, resuspended in sodium hydroxide $(0.3 \mathrm{M}, 8 \mathrm{ml})$ and incubated at $37^{\circ}$ for $1 \mathrm{~h}$. The protein was reprecipitated with perchloric acid $(200 \mathrm{~g} / \mathrm{l}$, $2 \mathrm{ml})$, collected by centrifugation and washed with $\mathrm{HClO}_{4}(40 \mathrm{~g} / 1,5 \mathrm{ml})$ to give a protein pellet which was then hydrolysed in hydrochloric acid $(6 \mathrm{M}, 5 \mathrm{ml})$ for $24 \mathrm{~h}$ at $110^{\circ}$ and dried in a vortex evaporator. The dry residue was washed four times with water $(1 \mathrm{ml})$ and resuspended in sodium citrate $(0 \cdot 5 \mathrm{M}, \mathrm{pH} 6 \cdot 3)$.

The specific activity of free phenylalanine in the supernatant fraction and the protein hydrolysate was measured after the enzymic conversion of phenylalanine to $\beta$-phenethylamine (Garlick et al. 1980). The radioactivity of $\beta$ - $\left[{ }^{3} \mathrm{H}\right]$ phenethylamine was measured by liquid-scintillation counting using Scintran Cocktail T (BDH Ltd, Poole, Dorset) in a Philips PW4700 liquid scintillation spectrometer.

Protein synthesis $\left(K_{s} ; \% / 15 \mathrm{~min}\right)$ was calculated from:

$$
K_{s}=\frac{S_{b}}{S_{a} \times t} \times 100,
$$

where $t$ is the incorporation time and $\mathrm{S}_{b}$ is the specific radioactivity of phenylalanine in tissue protein (McNurlan et al. 1979). $S_{a}$, the mean specific activity of free phenylalanine between zero time and $t$ was estimated from the values obtained for the groups of five animals killed at 5 and $15 \mathrm{~min} . K_{\delta}$ was determined for individual animals in the 15-min group by multiplying each free amino acid specific activity at $15 \min \left(S_{a} 15\right)$ by the value $S_{a} / S_{a} 15$ obtained from the group mean (Garlick et al. 1980). The actual times used in the calculation accounted for the period between killing the animal and cooling the tissue, which was 30-60 s. The specific activity of the free amino acid decreased between 5 and $15 \mathrm{~min}$ and values of $S_{a}$ were calculated on the basis of a linear change with time as described by Garlick et al. (1980).

Mucosal protein analysis was carried out on homogenates of fresh mucosa by a modification of the Lowry method (Lowry et al. 1951).

\section{Statistical methods}

The rate of cell division in the mucosa (cell divisions/crypt per $h$ ) was estimated by deriving the slope of the blocked metaphases $v$. time interval from injection to death, by the method of least squares. The standard error for the estimate of the slope was calculated and the 
Table 2. Body-weight gain, food intake, length of small intestine and mucosal weight for zinc-deficient, feed-restricted and ad lib.-fed control rats§

(Values are means with their standard errors for ten rats)

\begin{tabular}{|c|c|c|c|c|c|c|}
\hline \multirow[t]{2}{*}{ Dietary treatment... } & \multicolumn{2}{|c|}{ Zn-deficient } & \multicolumn{2}{|c|}{ Feed-restricted } & \multicolumn{2}{|c|}{ Ad lib. } \\
\hline & Mean & SE & Mean & SE & Mean & $\mathrm{SE}$ \\
\hline Body-weight gain $(g)^{\mid}$ & $68 * * *+\dagger \dagger$ & 2 & 81 & 3 & 167 & 4 \\
\hline Average food intake $(\mathrm{g})^{9}$ & $338+t+$ & 7 & $339+4+$ & 7 & 556 & 9 \\
\hline Length of small intestine (mm) & $930^{*}$ & 20 & $990^{\top 74}$ & 10 & 1020 & 20 \\
\hline $\begin{array}{l}\text { Total fresh weight of } \\
\text { jejunal mucosa }(\mathrm{g})\end{array}$ & $1 \cdot 22$ & 0.06 & $1 \cdot 16 \div$ & $0 \cdot 04$ & $1 \cdot 31$ & $0 \cdot 06$ \\
\hline Fresh weight of mucosa $(\mathrm{mg} / \mathrm{m})$ & $394^{*}$ & 18 & $348 \div$ & 11 & 386 & 11 \\
\hline
\end{tabular}

Statistical significance of difference between $\mathrm{Zn}$-deficient and feed-restricted groups: ${ }^{*} P<0 \cdot 05,{ }^{* * *} P<0.001$. Statistical significance of difference between $\mathrm{Zn}$-deficient and ad lib.-fed groups: $+\uparrow+P<0 \cdot 001$.

Statistical significance of difference between feed-restricted and ad lib-fed groups: $\ddagger P<0 \cdot 05, \ddagger \ddagger \ddagger P<0 \cdot 001$.

$\S$ For details of dietary treatments, see p. 596.

Gain over first $27 \mathrm{~d}$.

Average intake of five pairs of rats over $28 \mathrm{~d}$.

significance of differences between means was estimated using Student's $t$ test for unpaired comparisons. The significances of difference between other mean values were also assessed by Student's unpaired $t$ test.

\section{RESULTS}

The mean values for body-weight gain and food intake over the 28-d feeding period are shown in Table 2. Rats given the low-Zn diet consumed an average of $40 \%$ less food over this period than the ad lib.-fed control rats. The growth rate, as judged by body-weight, of the feed-restricted controls was significantly greater than that of the $\mathrm{Zn}$-deficient group despite the fact that they had consumed a similar amount of food. The growth curves for all three groups of rats over the first $27 \mathrm{~d}$ of the study are illustrated in Fig. 1. The Zn-deficient rats exhibited a progressive onset of the characteristic symptoms of the deficiency during this period including lethargy, hair loss and skin lesions.

The small intestines of the $\mathrm{Zn}$-depleted rats were shorter than those from the two control groups (Table 2). Small intestines taken from the feed-restricted controls were similar in length to those taken from the faster growing ad lib.-fed controls. The mean weight of mucosal tissue per unit length of jejunum from feed-restricted animals was, however, significantly reduced when compared with both the $\mathrm{Zn}$-depleted and ad lib.-fed control groups of rats (Table 2).

\section{Mucosal morphology}

The mean values for the ratio, crypt: villus and villus density in the jejunum of $\mathrm{Zn}$-deficient rats were significantly different from the values for both the control groups. It was noted that the number of crypts per villus progressively increased and the number of villi per $\mathrm{mm}^{2}$ jejunum progressively decreased from the $\mathrm{Zn}$-depleted to the feed-restricted to the ad lib.-fed group of animals. There were no significant changes in the number of crypts per $\mathrm{mm}^{2}$ mucosa (Table 3). 


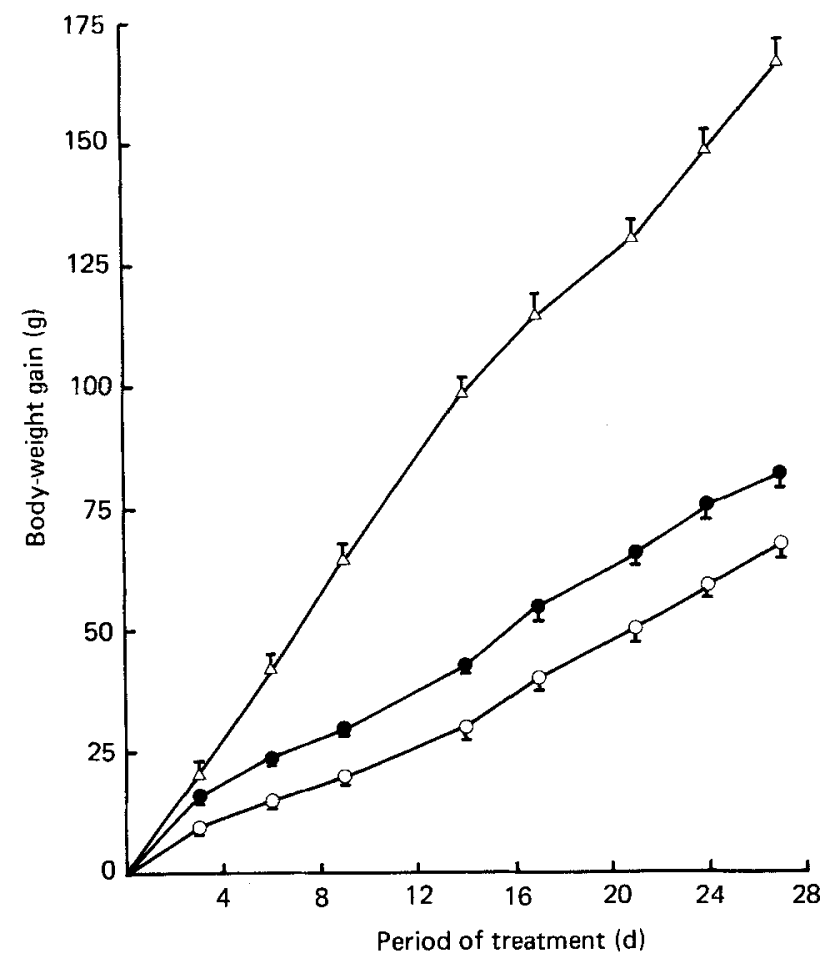

Fig. 1. Increase in body-weight (g) over $27 \mathrm{~d}$ for zinc-deficient $(O)$, feed-restricted control $(O)$ and $a d$ ibb.-fed control $(\triangle)$ rats. Values are means with their standard errors represented by vertical bars for ten rats. For details of dietary treatments, see p. 596.

\section{Cell production}

The cell division rate per crypt in the rats given a low-Zn diet was significantly lower than that for pair-fed controls given a $\mathrm{Zn}$-supplemented diet. The values for the ad lib.-fed control animals were more scattered than those for the other two groups and in consequence, although the estimated crypt-cell division for this group was higher than that for the $\mathrm{Zn}$-deficient group, the difference was not significant. The reduced rate of mucosal cell division in the jejunum of $\mathrm{Zn}$-deficient rats, coupled with a low crypt: villus value, resulted in the net cell division rate per villus being markedly lower than for either of the two control groups (Table 3). The difference between the $\mathrm{Zn}$-deficient group and the two control groups becomes slightly less marked when cell production rate is expressed in terms of unit area of jejunum.

\section{Protein synthesis}

The mean specific activity of free phenylalanine at time intervals after injection is shown in Table 4. The specific radioactivity in the mucosa of the feed-restricted animals was a little higher at $5 \mathrm{~min}$ and declined less rapidly with time than for the other two groups.

The mean values for protein content per unit fresh weight and fractional rates of protein synthesis in jejunal mucosa of the three groups of rats were not significantly different and showed no evidence of reduced rates of protein synthesis in the $\mathrm{Zn}$-deficient animals. It was noted, however, that both values were lowest for the feed-restricted controls (Table 5). 
Table 3. Morphology and crypt cell production rate in jejunal mucosa for zinc-deficient, feed-restricted and ad lib.-fed control rats $\ddagger$

(Values are means with their standard errors for five rats)

\begin{tabular}{|c|c|c|c|c|c|c|}
\hline \multirow[t]{2}{*}{ Dietary treatment... } & \multicolumn{2}{|c|}{ Zn-deficient } & \multicolumn{2}{|c|}{ Feed-reștricted } & \multicolumn{2}{|c|}{$A d$ lib.-fed } \\
\hline & Mean & $\mathrm{SE}$ & Mean & $\mathrm{SE}$ & Mean & SE \\
\hline Villi $\left(/ \mathrm{mm}^{2}\right)$ & $19 * \dagger+\dagger$ & 0.4 & 17 & 0.4 & 15 & $0 \cdot 5$ \\
\hline Crypts $\left(/ \mathrm{mm}^{2}\right)$ & 376 & 6 & 390 & 7 & 374 & 6 \\
\hline Crypt: villus value & $20^{*} \dagger \dagger$ & 1 & 23 & 1 & 25 & 1 \\
\hline \multicolumn{7}{|l|}{ Crypt cell production rates: } \\
\hline No. of cells/crypt per h & $10^{* * *}$ & 1 & 14 & 1 & 13 & 3 \\
\hline No. of cells/villus per $h$ & $200^{* *}$ & 22 & 322 & 27 & 325 & 76 \\
\hline No. of cells $/ \mathrm{mm}^{2}$ per $h$ & $3760^{* *}$ & 381 & 5460 & 402 & 4862 & 1124 \\
\hline
\end{tabular}

Statistical significance of difference between $\mathrm{Zn}$-deficient and feed-restricted groups: ${ }^{*} P<0.05,{ }^{* *} P<0.01$, *** $P<0.001$.

Statistical significance of difference between $\mathrm{Zn}$-deficient and ad lib.-fed groups: $\uparrow+P<0 \cdot 01, \dagger+\dagger P<0 \cdot 001$.

\$ For details of dietary treatments, see p. 596.

Table 4. Specific radioactivity (disintegrations/min per $\mathrm{mmol}$ ) of free $L-\left[4-{ }^{3} H\right]$ phenylalanine in jejunal mucosa for zinc-deficient, feed-restricted and ad lib.-fed control rats*

(Values are means with their standard errors for five rats)

\begin{tabular}{|c|c|c|c|c|}
\hline \multirow[b]{3}{*}{ Dietary treatment } & \multicolumn{4}{|c|}{ Time interval after injection (min) } \\
\hline & \multicolumn{2}{|c|}{5} & \multicolumn{2}{|c|}{15} \\
\hline & Mean & SE & Mean & SE \\
\hline $\mathrm{Zn}$-deficient & 449 & 68 & 391 & 28 \\
\hline Feed-restricted & 484 & 10 & 461 & 15 \\
\hline Ad lib.-fed & 432 & 11 & 393 & 17 \\
\hline
\end{tabular}

* For details of dietary treatments, see p. 596.

Table 5. Total protein content and fractional rates of protein synthesis in jejunal mucosa for zinc-deficient, feed-restricted and ad lib.-fed control rats*

(Values are means with their standard errors for five rats)

\begin{tabular}{llcccc}
\hline & $\begin{array}{c}\text { Protein } \\
(\mathrm{mg} / \mathrm{g} \text { fresh mucosa) }\end{array}$ & & $\begin{array}{c}\text { Fractional synthesis rate } \\
(\% / 15 \mathrm{~min})\end{array}$ \\
\cline { 2 - 3 } Dietary treatment & Mean & SE & & Mean & SE \\
\hline Zn-deficient & 179 & 9 & & 0.92 & 5 \\
Feed-restricted & 167 & 10 & & 0.79 & 4 \\
Ad lib.-fed & 183 & 2 & & 0.88 & 5 \\
\hline
\end{tabular}

* For details of dietary treatments, see p. 596. 


\section{DISCUSSION}

$\mathrm{Zn}$ deficiency manifests itself in many ways including severe retardation of growth and development and a reduction in the efficiency of food utilization (Mills et al. 1969; Paullauf, 1978). $\mathrm{Zn}$ is an integral constituent of DNA polymerases, reverse transcriptase, RNA polymerases, tRNA synthetases and protein chain elongation factor (Vallee \& Falchuck, 1981). In addition, there is a specific requirement for $\mathrm{Zn}$ by thymidine kinase $(E C 2.7$.1 .75) (Duncan \& Dreosti, 1976) and it also appears to regulate the activity of ribonucleases (Chesters \& Will, 1978). It has been suggested that changes in the activities of these enzymes are responsible for the decreased protein synthesis and growth retardation observed in many animal species consuming low- $\mathrm{Zn}$ diets. The amount of $\mathrm{Zn}$ in many tissues is not materially affected even after prolonged dietary depletion and a decrease in the activity of $\mathrm{Zn}$ metalloenzymes is often difficult to demonstrate (Burch et al. 1975). The severe and relatively rapid reduction in growth rate resulting from low levels of dietary $\mathrm{Zn}$ cannot therefore be adequately explained in terms of a generalized reduction in cell proliferation and maturation.

Since all nutrients enter the body by way of the gastrointestinal tract, any structural or functional changes therein could result in an overall effect on growth rate and nutrient utilization. In view of the rapid rate of cell turnover in the intestinal mucosa and the requirement for $\mathrm{Zn}$ for normal cell division and development, it is likely that dietary $\mathrm{Zn}$ depletion would produce alterations in both the growth and function of this tissue.

In a previous study we found that $\mathrm{Zn}$ deficiency in the rat was indeed associated with shortening and narrowing of jejunal villi and an increased number of villi per unit area of serosa (Southon et al. 1984). The present study demonstrates that these morphological changes are accompanied by a reduction in the production of new cells, a smaller number of crypts per villus and, hence, a substantial decrease in the influx of cells into each villus. The smaller villi associated with dietary $\mathrm{Zn}$ depletion may be a direct result of the reduction in crypt cell division since production and loss of cells must each remain constant in order that the villus morphology may be preserved (Creamer, 1974). This decrease in mucosal cell proliferation is, perhaps, not surprising in view of the many reports that dietary $\mathrm{Zn}$ depletion results in reduced thymidine kinase activity and an inhibition of DNA synthesis in rapidly dividing cells (Swenerton et al. 1969; Sandstead \& Rinaldi, 1973; Prasad \& Oberleas, 1974). It is interesting to note, however, that Fell et al. (1973) reported an increase in the mitotic index of oesophageal and buccal mucosa of $\mathrm{Zn}$-deficient rats, suggesting a difference in the effect of $\mathrm{Zn}$-depletion in these tissues.

In the present study, although the level of dietary $\mathrm{Zn}$ depletion was sufficient to reduce cell influx into the jejunal villi, there was no evidence of a decline in the protein synthetic rate in total mucosal scrapes, neither was there any relation between cell production rate and the rate of protein synthesis. This contrasts with a previous observation that a reduction in mucosal cell proliferation in rats given a semi-synthetic diet was accompanied by a significant decrease in the fractional rate of protein synthesis when compared with rats given a commercially prepared, pelleted diet (Southon et al. 1985). In addition, there is evidence that intestinal RNA and protein synthesis are lower in resting crypt cells than in the proliferating cells (Deschner \& Lipkin, 1970) which also implies that changes in the rate of mucosal cell division could lead to reduced protein synthetic activity. Values for the fractional rate of protein synthesis in total mucosal samples from $\mathrm{Zn}$-deficient rats, however, tended to be higher than those for feed-restricted control rats, despite the lower rate of crypt cell production. Each group of rats was allowed access to food up to 2-6 $\mathrm{h}$ before killing; it is unlikely therefore that a reduction in protein synthetic activity in the mucosa of the pair-fed animals was due to the absence of digesta in the lumen. However, since the values 
for fractional rates of synthesis were similar in the ad lib.-fed groups of rats, whether plus or minus $\mathrm{Zn}$, it is possible that the meal-feeding pattern of food intake exhibited by the pair-fed control animals might have affected protein synthetic activity in the mucosal tissue. A second possibility is that dietary $\mathrm{Zn}$ depletion resulted in an increased rate of protein synthesis in the maturing enterocytes.

In a previous report (Southon et al. 1984) we postulated that, since cell production in the crypts is closely linked to the rate of cell migration along the villus surface and cell loss from the villus tip (Clarke, 1973), a reduction in mucosal cell proliferation in Zn-deficient animals was likely to be associated with a slowing of cell migration. This in turn might result in the presence of a relatively greater proportion of mature enterocytes along the villus surface. During maturation there are rapid changes in the enzymic activity and the absorptive capacity of mammalian enterocytes (Kinter \& Wilson, 1965; Imondi et al. 1969). An increase in the numbers of fully differentiated cells in the mucosa could provide an explanation for the maintenance of the rate of protein synthesis observed in total mucosa of the $\mathrm{Zn}$-depleted rats in the present study, and for the marked enhancement of hexose uptake into jejunum of $\mathrm{Zn}$-depleted animals observed in a previous in vitro study (Southon et al. 1984). Indirect support for this supposition is given by evidence that increased proliferative activity in mucosal crypts results in a marked decrease in the activity of several bursh-border enzymes involved in villus function (Galjaard et al. 1970; de Both et al. 1974; Rijke et al. 1975). The biochemical changes which result in this phenomenon are poorly understood but it may well be that the reverse is also true, that is, a decreased cell proliferation is accompanied by increased enzymic activity and absorptive capacity.

It may be argued that, since mucosal cell proliferation in the jejunum and the size of the jejunal villi are both reduced in $\mathrm{Zn}$-deficient rats, mucosal cell turnover time might be similar to that for the control animals despite a slower rate of cell migration. We have found, however, that whereas the net cell influx into each villus of the $\mathrm{Zn}$-depleted rats is reduced by $38 \%$ when compared with feed-restricted and ad lib-fed controls, the surface area of the villus is reduced by only 24 and $29 \%$ respectively (the surface area per villus being 0.29 (SE $0.02) \mathrm{mm}^{2}$, Zn-deficient group; 0.38 (SE 0.03 ) $\mathrm{mm}^{2}$, feed-restricted group; 0.41 (SE $0.02) \mathrm{mm}^{2}$, ad lib.-fed group; unpublished results). This supports the suggestion that mucosal cell life-span is likely to be increased in the animals fed on a low-Zn diet.

It is interesting to compare the effects on mucosal growth of dietary $\mathrm{Zn}$-depletion and its concomitant reduction in voluntary food intake, with restricted intake of a $\mathrm{Zn}$-adequate diet. Cell production rate and net cell influx into the jejunal villi were similar in feed-restricted and ad lib.-fed controls, whereas there was a substantial decrease in the influx of new cells into the villi of $\mathrm{Zn}$-depleted rats. Restricted consumption of a $\mathrm{Zn}$-adequate diet resulted in a decrease in the weight of mucosal tissue per unit length of jejunum, larger numbers of slightly smaller villi per unit area (Southon et al. 1984) and a marginally lower crypt: villus value when compared with rats allowed to feed ad lib. Dietary $\mathrm{Zn}$-depletion also resulted in a decrease in villus dimensions (Southon et al. 1984), an increase in the number of villi per unit area of jejunum and a lower crypt: villus value, but these changes were significantly greater than those resulting from restricted consumption of a $\mathrm{Zn}$-adequate diet. Mucosal mass per unit length of jejunum was not reduced in the $\mathrm{Zn}$-depleted animals. Both the $\mathrm{Zn}$-depleted and feed-restricted control rats responded to nutrient restriction by producing larger numbers of smaller villi per unit area of small intestine, thereby maintaining absorptive surface, but these morphological changes were more pronounced in the $\mathrm{Zn}$-depleted animals. The reduction in the influx of new cells into the villi appears to be the result of $\mathrm{Zn}$-deficiency per se. 
The authors thank Mrs J. Cooke, Mr P. Muddel, Miss J. Brown and Mrs Z. Piper for animal care and technical assistance.

\section{REFERENCES}

Burch, R. E., Williams, R. V., Hahn, H. K. J., Jetton, M. M. \& Sullivan, J. F. (1975). Clinical Chemistry 21, $568-577$.

Chesters, J. K. \& Will, M. (1978). British Journal of Nutrition 39, 375-382.

Clarke, R. M. (1970). Journal of Anatomy 107, 519-529.

Clarke, R. M. (1973). Digestion 8, 161-175.

Creamer, B. (1974). In The Small Intestine, pp. 1-23 [B. Creamer, editor]. London: Heinemann.

de Both, N. J., van Dongen, J. M., van Hofwegen, B., Keulemans, J., Visser, W. J. \& Galjaard, H. (1974). Developmental Biology 38, 119-137.

Deschner, J. R. \& Lipkin, M. (1970). Journal of the National Cancer Institute 44, 175-185.

Duncan, J. R. \& Dreosti, I. E. (1976). Journal of Comparative Pathology 86, 81-85.

Fell, B. F., Leigh, L. C. \& Williams, R. B. (1973). Research in Veterinary Science 14, 317-325.

Galjaard, H., Buys, J., van Duuren, M. \& Geisen, J. (1970). Journal of Histochemistry and Cytochemistry 18, 291-301.

Garlick, P. J., McNurlan, M. A. \& Preedy, V. R. (1980). Biochemical Journal 204, 393- 398.

Imondi, A. R., Bayliss, M. E. \& Lipkin, M. (1969). Experimental Cell Research 58, 323-330.

Kinter, W. B. \& Wilson, T. H. (1965). Journal of Cell Biology 25, 19-39.

Lipkin, M., Sherlock, P. \& Bell, B. (1963). Gastroenterology 45, 721-729.

Lowry, O. H., Rosebrough, N. J., Farr, L. A. \& Randall, R. J. (1951). Journal of Biological Chemistry 193, 265-275.

McNurlan, M. A., Tomkins, A. M. \& Garlick, P. J. (1979). Biochemical Journal 178, 373-379.

Messier, B. \& Leblond, C. P. (1960). American Journal of Anatomy 106, 247-294.

Mills, C. F., Quaterman, J., Chesters, J. K., Williams, R. B. \& Dalgarno, A. C. (1969). American Journal of Clinical Nutrition 22, 1240-1249.

Paullauf, J. (1978). In Trace Element Metabolism in Man and Animals, vol. 3, pp. 218-221 [M. Kirchgessner, editor]. München Institut für Ernahrungs-Physiologie, Technische Universität München.

Prasad, A. S. \& Oberleas, D. (1973). Journal of Laboratory and Clinical Medicine 82, 461-466.

Prasad, A. S. \& Oberleas, D. (1974). Journal of Laboratory and Clinical Medicine 83, 634-639.

Reeds, P. J., Haggarty, P., Wahle, W. J. \& Fletcher, J. M. (1982). Biochemical Journal 204, 393-398.

Rijke, R. P. C., Plaisier, H., Hoovgeveen, A. T., Lamerton, L. F. \& Galjaard, H. (1975). Cell and Tissue Kinetics 8, 441-453.

Sandstead, H. H. \& Rinaldi, R. A. (1973). Journal of Cell Physiology 73, 81-84.

Southon, S., Gee, J. M. \& Johnson, I. T. (1984). British Journal of Nutrition 52, 371-380.

Southon, S., Livesey, G., Gee, J. M. \& Johnson, I. T. (1985). British Journal of Nutrition 53, 87-95.

Swenerton, H., Schrader, R. \& Hurley, L. S. (1969). Science 166, 1014-1015.

Vallee, B. L. \& Falchuck, K. H. (1981). Philosophical Transactions of the Royal Society 294, $185-197$.

Wimber, D. E. \& Lamberton, L. F. (1963). Radiation Research 18, 137-146. 